\title{
Meta-analysis of the application effects of a biostimulant based on extracts of yeast and amino acids on off-season corn yield
}

\section{Metanálise do efeito da aplicação de bioestimulante à base de extratos de leveduras e aminoácidos na produtividade de milho safrinha}

\author{
André Luis da Silva ${ }^{1 *}$; Marcelo Giovanetti Canteri²; Alexandre José da Silva \\ Marina Faria Bracale ${ }^{4}$
}

\begin{abstract}
The tests were performed with a biostimulant (GAAP) containing yeast extract and amino acids. The yield data of the off-season corn for meta-analysis were collected from 41 trials conducted in the states of Paraná, São Paulo, Mato Grosso, Minas Gerais, and Goiás during the 2013/2014 crop season. The tests consisted of eight treatments, with four replicates per treatment, and were conducted on $3.6 \times 6.0 \mathrm{~m}$ plots. The treatments consisted of application of biostimulant at $2.0 \mathrm{~L} \mathrm{ha}^{-1}$ at different times and the control (no biostimulant). The time of application corresponded to the growth stages, V8, VT, R1, (V8 + VT), $(\mathrm{V} 8+\mathrm{R} 1),(\mathrm{VT}+\mathrm{R} 1)$, and $(\mathrm{V} 8+\mathrm{VT}+\mathrm{R} 1)$. The influence of biostimulant application was quantified as the difference in yield, expressed as kilogram per hectare $\left(\mathrm{kg} \mathrm{ha}^{-1}\right)$, between treatments and the control (effect measurements). Meta-analysis was used to study the effects of the treatments and to calculate the probability of yield increase with product use. The meta-analysis was performed using the software $R$. The random effects model was used for meta-analysis because of the high heterogeneity among the studies. Next, the mixed effect model was applied to explain the high heterogeneity, considering the following subgroups: the number of applications, the timing of applications, the presence of water stress, and the region where the tests were conducted. The probability of yield increase was calculated at the levels of 2, 5, and 10 bags, each of $60 \mathrm{~kg} \mathrm{ha}^{-1}$. The meta-analysis results for the variable "General" and the subgroups were significantly positive $(\mathrm{p}<0.0001)$, with a meta-analytic estimate of $342.1 \mathrm{~kg}$ $\mathrm{ha}^{-1}$ and the confidence interval for $95 \%$ probability ranging between $301.2 \mathrm{~kg} \mathrm{ha}^{-1}$ and $383.0 \mathrm{~kg} \mathrm{ha}^{-1}$. The probability for yield greater than zero or equal to 2, 5, and 10 bags of $60 \mathrm{~kg} \mathrm{ha}^{-1}$ in subgroup "three applications" was $91.7 \%, 85.4 \%, 71.0 \%$, and $38.9 \%$, respectively. These same values were estimated at $91.7 \%, 85.4 \%, 71.0 \%$, and $39.0 \%$ for the variable "applications in V8 + VT + R1"; $79.1 \%, 69.3 \%$, $50.1 \%$, and $21.1 \%$ for the variable "trials under stress condition"; and $84.2 \%, 75.1 \%, 57.7 \%$, and $26.9 \%$ for the variable "investments made in Southern Brazil," respectively. The meta-analysis of the data from 287 effect measurements generated in 41 trials demonstrated that foliar application of GAAP biostimulant increases corn yield by $342.1 \mathrm{~kg} \mathrm{ha}^{-1}$ with $83.7 \%$ probability of positive response.
\end{abstract}

Key words: Foliar application. Forest plot. Meta-analytic estimate. Quantis.

\footnotetext{
1 Discente de Doutorado em Fitopatologia, Departamento de Agronomia, Universidade Estadual de Londrina, UEL, Londrina, PR, Brasil. E-mail: andreluis111@gmail.com

2 Prof. Dr. Associado, Fitopatologia, Departamento de Agronomia, UEL, Londrina, PR, Brasil. E-mail: canteri@uel.br

3 Discente de Doutorado em Agronomia, Departamento de Agronomia, Instituto Agronômico de Campinas, IAC, Campinas, SP, Brasil. E-mail: aleagro62@hotmail.com

4 Discente de Mestrado em Fitopatologia, Departamento de Agronomia, UEL, Londrina, PR, Brasil. E-mail: marina.bracale@, gmail.com

* Author for correspondence
} 


\section{Resumo}

Os testes foram realizados com um bioestimulante (AAAP) o qual contém em sua composição extratos de leveduras e aminoácidos. Os dados de produtividade de milho safrinha para metanálise foram coletados de 41 ensaios, nos estados do Paraná, São Paulo, Mato Grosso, Minas Gerais e Goiás no ano agrícola de 2013/2014. Os ensaios constituíam-se de 8 tratamentos com quatro repetições, com parcelas de tamanho de $3,6 \times 6,0 \mathrm{~m}$. Os tratamentos testados eram compostos pela testemunha (sem aplicação de bioestimulante) e os demais tratamentos foram formados pela variação na época de aplicação do bioestimulante na dose de 2,0 $\mathrm{L} \mathrm{ha}^{-1}$. As épocas corresponderam aos estádios fenológicos V8, VT, R1, (V8+VT), (V8+R1), (VT+R1) e (V8+VT+R1). Avaliou-se a produtividade em $\mathrm{kg} \mathrm{ha}^{-1}$ e com base nas diferenças entre tratamentos e testemunha (medidas de efeito), quantificou-se a influência da aplicação do bioestimulante. A metanálise foi utilizada para estudar os efeitos dos tratamentos e para o cálculo da probabilidade de incremento em produtividade com o uso do produto. A metanálise foi realizada usando-se o software R. O modelo de efeitos aleatórios foi utilizado para metanálise pois constatouse alta heterogeneidade entre os estudos. Posteriormente aplicou-se o modelo de efeito misto, afim de explicar a alta heterogeneidade, onde, definiram-se as variáveis moderadoras em função do número de aplicações, época das aplicações, ocorrência de stress hídrico e região onde foram conduzidos os ensaios. Em posse da estimativa metanalítica das variáveis moderadoras calculou-se a probabilidade de incremento em produtividade nos níveis de 2, 5 e 10 sacas de $60 \mathrm{~kg} \mathrm{ha}^{-1}$. Os resultados da metanálise para variável "Geral" e as variáveis moderadoras foram significativamente positivos ( $\mathrm{p}$-valor $<0,0001)$ com estimativa metanalítica de $342,1 \mathrm{~kg} \mathrm{ha}^{-1}$ e intervalo de confiança $95 \%$ de probabilidade, entre $301,2 \mathrm{~kg}$ ha $^{-1}$ e $383,0 \mathrm{~kg} \mathrm{ha}^{-1}$. A variável moderadora " 3 aplicações" apresentou probabilidades de $91,7 \%, 85,4 \%$, $71,0 \%$ e $38,9 \%$, respectivamente para apresentar produtividade acima de zero e nos níveis de 2,5 e 10 sacas $60 \mathrm{~kg} \mathrm{ha}^{-1}$. Estes mesmos valores foram $91,7 \%, 85,4 \%, 71,0 \%$ e 39,0\% para a variável "aplicações realizadas em V8+VT+R1", 79,1\%, 69,3\%, 50,1\% e 21,1\% para a variável "ensaios realizados sob condição de stress" e 84,2\%, 75,1\%, 57,7\% e 26,9\% para a variável "aplicações realizadas na região Sul do Brasil". Demonstrou-se através da metanálise que a aplicação foliar do bioestimulante incrementou a produtividade do milho com $83,7 \%$ de probabilidade de resposta positiva, com dados de 287 medidas de efeito geradas em 41 ensaios.

Palavras-chave: Aplicação foliar. Estimativa Metanalítica. Forest plot. Quantis.

\section{Introduction}

Brazil is the third largest producer of corn worldwide, with a production of 85.45 million tons, in an area of 15.8 million hectares, and an average yield of $5401 \mathrm{~kg} \mathrm{ha}^{-1}$ (CONAB, 2015).

Corn production in Brazil is characterized by two sowing seasons. Summer sowing, or the first harvest, is traditionally performed during the rainy season, varying between the end of August in the South Region and October/November in the Southeast and Central-West regions (in the Northeast, it occurs at the beginning of the year). Off-season sowing is performed predominantly in the Central-West Region and the states of Paraná and São Paulo using drought corn in February or March, almost always following early soybean crops (EMBRAPA, 2008).
New technologies, together with genetic improvement and adequate management, are used to increase corn yield. The use of biostimulants stands out, because they are natural or synthetic substances that can be applied to seeds, plants, and soil, changing vital and structural plant processes and increasing plant yield (ÁVILA et al., 2008). Biostimulants have been used in different crops to promote plant development. They are mixtures of plant hormones with different biochemical compounds, such as amino acids, vitamins, seaweed, micronutrients, and ascorbic acid (VIEIRA, 2001). These complexes promote plant hormone balance, favoring the realization of plant's genetic potential and stimulating root development (ONO et al., 1999). Biostimulants affect the degradation of seed reserves and cell differentiation, division, and elongation (CASTRO; VIEIRA, 2001). Over 
the last few years, the use of biostimulants has increased as an agricultural technique to optimize the yield of several crops. The hormones contained in biostimulants are signaling molecules, naturally present in plants in small concentrations, with important effects on plant development (TAIZ; ZEIGER, 2004).

Leaf cuticle is highly permeable to amino acids. Foliar application of nutrients (minerals) chelated to amino acids results in higher absorption efficiency and speed than simple free cation diffusion. Chelation removes the ionic charge of the elements (nutrients), which are thus not subjected to attraction or repulsion forces, in the leaf cuticle (HSU, 1986). Plants can take up most essential amino acids through leaves and/or roots. Foliar uptake is the most utilized because the nutrient can be applied together with other agrochemicals, such as herbicides, insecticides, and especially fungicides, and their association with amino acids may increase their absorption rate by plants (MALAVOLTA, 1980). Conflicting results have been observed in the use of biostimulants due to the absence of significant differences in yield in many studies. Csinzinszky (1990) tested two bell pepper cultivars and six biostimulants applied according to the manufacturers' recommendations. The author observed no effect of the biostimulants on plant yield or nutrient content-plant development was similar to the control for one of the cultivars and lower for the other cultivar.

Tweddell et al. (2000) applied a biostimulant to corn plants subjected to different levels of nitrogen fertilization and observed no significant differences in grain yield, dry biomass, and leaf nutrient concentrations. Vasconcelos (2006) reported that biostimulant application did not increase plant dry matter production, size, photochemical efficiency, and protein and nutrient concentrations in corn and soybean and the yield did not increase significantly. Janegitz et al. (2008) analyzed the effects of four biostimulants (Bioamino Extra ${ }^{\circledR}$, Aminolom $^{\circledR}, \mathrm{Pt} 4{ }^{\circledR}$, and $\operatorname{Radix}^{\circledR}$ ) on corn and sorghum plant emergence and observed higher values for corn than for sorghum, but the differences were not significant between the treatments. Belanson (2008) tested the effect of different biostimulants (hormone-, micronutrient-, amino acid- and vitamin-based) on wheat and confirmed their ability to promote rooting. However, the author observed no increase in plant size, average grain weight per spike, or grain yield. Della Libera (2010) observed no differences in corn yield with application of biostimulants in the 2009/2010 harvest.

Trials are usually analyzed separately, and even if no statistically significant differences are observed between treatments, tendency in yield increase with biostimulant application is often observed. Metaanalysis is a suitable tool for these cases, because it allows the analysis of large data sets and the detection of statistically significant effects even when the observed differences are small.

Meta-analysis is applied to large data sets to estimate the size, consistency, and homogeneity of a given effect (ROSENBERG et al. 2004; BORENSTEIN et al. 2009; RODRIGUES; ZIEGELMANN, 2010; MADDEN; PAUL, 2011; NGUGI et al., 2011). The different studies included in the meta-analysis can have different effects and weights on its results (BORENSTEIN et al. 2009).

In Brazil, meta-analysis has been used in many different agricultural studies (DALLA LANA et al., 2015; CALVO et al., 2016; FANTIN et al., 2016).

Meta-analysis is a quantitative method, i.e., to perform a meta-analysis, it is not enough to perform a quantitative analysis of the results of previous studies, but a new statistical analysis of the collected data or results needs to be performed in order to draw conclusions. Meta-analyses allow reaching conclusions in the case of apparently conflicting results (BOISSEL et al., 1989; BOISSEL, 1994; D'AGOSTINO; WEINTRAUB, 1995). A metaanalysis is a systematic statistical synthesis of prior results on a given subject, with an emphasis on the generation of quantitative conclusions. It therefore 
differs from the narrative reviews used in theses and dissertations. It allows us to reach statistically significant conclusions for variables for which no statistically significant effects are observed under traditional experimentation in isolated trials.

Although the application of biostimulants was confirmed to have positive effect on plants, the effect of biostimulant foliar application on corn yield is still debated. The aim of the present study was to perform a meta-analysis of the effects of biostimulant application on the off-season corn yield in 41 trials.

\section{Material and Methods}

The data used for the analysis were obtained from a network of trials of a biostimulant (GAAP) containing yeast extract, amino acids (glutamic acid, aspartic acid, alanine, and proline), $9 \% \mathrm{~K}_{2} \mathrm{O}$, $1 \% \mathrm{~N}, 1 \% \mathrm{Ca}$ and $15 \%$ organic carbon, with the commercial name Quantis ${ }^{\circledR}$. Quantis is a trademark of Syngenta Proteção de Cultivos Ltd. in Brazil, which authorized this study and supplied the data about its performance. No previously published data on this subject were used, but only data from trials performed within the trial network. Data from a total of 41 trials were used; these trials were conducted in the states of Paraná, São Paulo, Mato Grosso, Minas Gerais, and Goiás, on the off-season corn crops, during the 2013/2014 crop year. Each trial consisted of eight treatments, with four replicates per treatment. The plots were $3.6 \mathrm{~m}$ in width and 6 $\mathrm{m}$ in length, in a total area of $21.6 \mathrm{~m}^{2}$. A randomized blocks experimental design was used.

The tested treatments consisted of different times of application of the biostimulant and a control without biostimulant application. The different times of application corresponded to different phenological stages, vegetative $(\mathrm{V})$ and reproductive (R): V8, VT, R1, V8+VT, V8+R1, VT+R1, and $\mathrm{V} 8+\mathrm{VT}+\mathrm{R} 1$. The biostimulant was applied in doses of $2.0 \mathrm{~L} \mathrm{ha}^{-1}$. The applications were performed using a $\mathrm{CO}_{2}$-pressurized backpack sprayer with a $3.5 \mathrm{~m}$ boom with six fan nozzles XRTJ11002 spaced $0.5 \mathrm{~m}$ apart, delivering $200 \mathrm{~L} \mathrm{ha}^{-1}$, at a constant pressure of $30 \mathrm{lb} \mathrm{pol}^{2}$. Weed, pest, and disease management was performed by herbicide, insecticide, and fungicide application.

The yield was estimated by harvesting an area of $7.2 \mathrm{~m}^{2}(1.80 \mathrm{~m} \times 4.00 \mathrm{~m})$ from each plot. The data were corrected for $13 \%$ moisture and converted to kilogram per hectare $\left(\mathrm{kg} \mathrm{ha}^{-1}\right)$. Treatment effects were quantified by calculating the yield difference between treated and non-treated plots according to the method described by Paul et al. (2010) and adapted from Arends et al. $(2000 ; 2003)$.

Meta-analysis was initially performed by estimating the effect measurements or yield response $\left(\mathrm{kg} \mathrm{ha}^{-1}\right)$ as the difference between the treatment group (with biostimulant application) and the control group (without biostimulant application). The size of the effect measurement indicates the effect of biostimulant application on grain yield in corn crops. Standard deviation for each trial (Equation 1) and standard error for each treatment (Equation 2) were calculated from the effect measurements. The standard error was used as a dispersion or weight measure in the meta-analysis.

$$
\sigma=\left(\mathrm{CV}^{*} \overline{\mathrm{y}}\right) / 100
$$

Standard deviation $(\sigma)$ was calculated as the product of the coefficient of variation (cv) and the overall average of yield differences between treatment and control ( $\bar{y})$, divided by 100 .

Standard error (SE) was calculated by dividing the standard deviation $(\sigma)$ by the square root of the number of replicates $(n)$ for each trial.

$$
\mathrm{SE}=\sigma / \sqrt{ } \mathrm{n}
$$

Following data tabulation for the 41 trials, 287 effect measurements were calculated (41 trials $\times 7$ treatments). On the worksheet, the data were grouped according to the number of applications (1, 2, or 3), the time of application (V8, VT, R1, V8+VT, $\mathrm{V} 8+\mathrm{R} 1, \mathrm{VT}+\mathrm{R} 1$, or $\mathrm{V} 8+\mathrm{VT}+\mathrm{R} 1)$, the presence of water stress during the trial (with and without), and 
the region where the trial was conducted (South and Cerrado region).

Using these data, a forest plot was generated for yield in bags of $60 \mathrm{~kg} \mathrm{ha}^{-1}$ (Figure 1) to analyze the treatment effects and standard error. Using the treatment effect, standard deviation, and standard error, meta-analytic models were fitted using the Metafor 1.9-8 package in the $\mathrm{R}$ software ( $\mathrm{R}$ DEVELOPMENT CORE TEAM, 2015).

Figure 1. Off-season corn yield differences between treatments with and without (control) foliar application of biostimulant (bars), and respective standard deviations (lines), for the 287 effect measurements obtained for 41 trials analyzed.

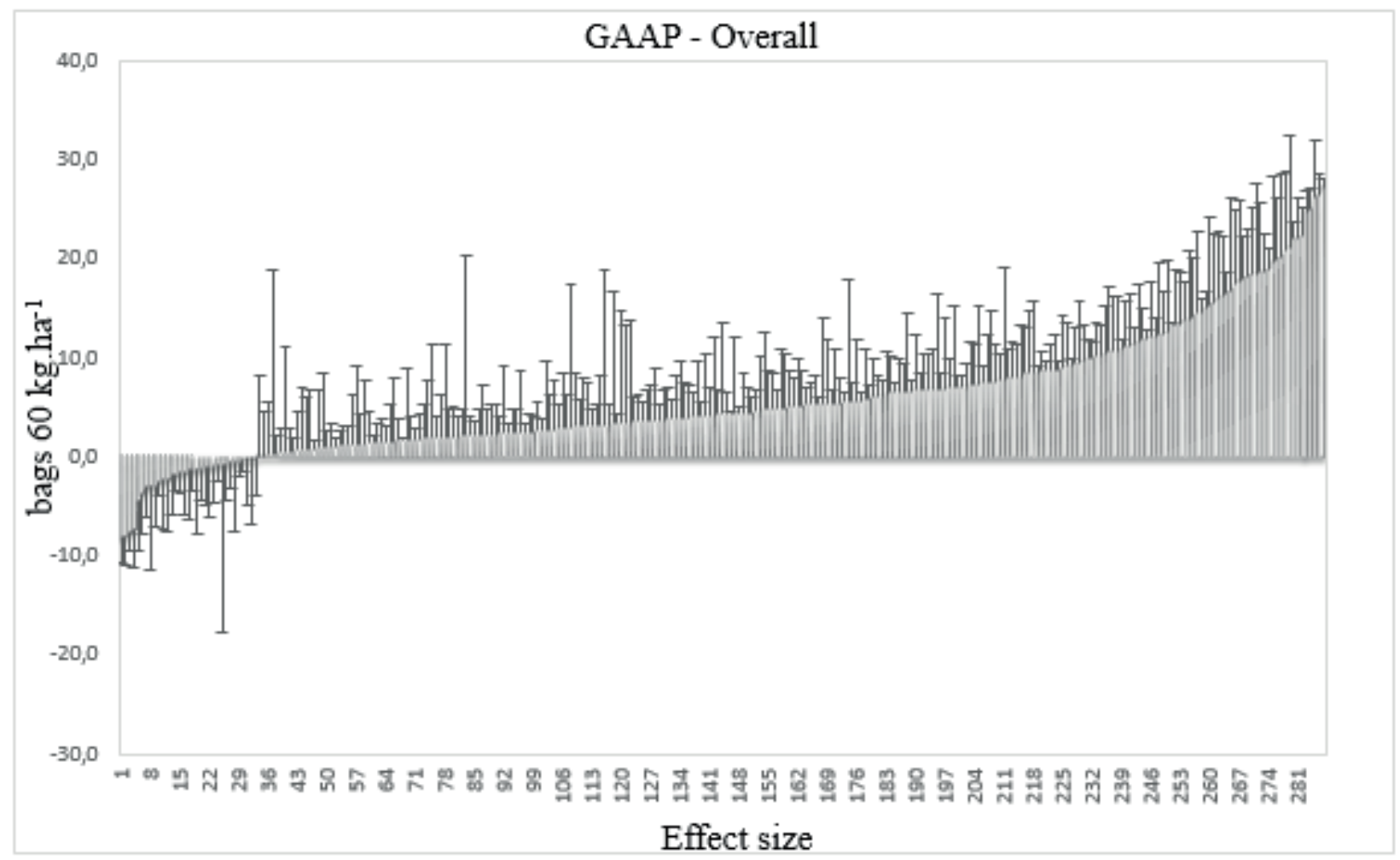

When the sampled data sethas normal distribution, the treatment effect may vary between studies, and using the random effect model is recommended (BORENSTEIN et al., 2009; MADDEN; PAUL, 2011). In addition to the sampling error considered in the fixed-effects model, the random-effect model also takes into account variation between studies, which is important to obtain a measure of dispersion for each study such as standard deviation, variance, or coefficient of variation (BORENSTEIN et al. 2009; FIELD; GILLETT, 2010; RODRIGUES; ZIEGELMANN, 2010; MADDEN; PAUL, 2011; NGUGI et al. 2011). Heterogeneity was calculated using the $I^{2}$ statistics (HIGGINS; THOMPSON, 2002; HIGGINS et al., 2003), which considers that the heterogeneity of effect measurements between studies is formed by two sources of variation, true heterogeneity and random sampling error (RODRIGUES; ZIEGELMAN, 2010).

After estimating the global effect measurement, fixed-effect explanatory variables were introduced to the random-effect model, generating a mixedeffects model. The explanatory variables were defined based on trial characteristics that could explain the variation between them. Four moderator 
variables and respective groups were defined: 1) Number of biostimulant applications (1, 2, or 3); 2) Time of application (V8, VT, R1, V8+VT, V8+R1, $\mathrm{VT}+\mathrm{R} 1$ or $\mathrm{V} 8+\mathrm{VT}+\mathrm{R} 1$ ); 3) Presence of water stress during the trial (with or without); and 4) Region in which the trial was performed (South and Cerrado regions). A mixed-effects model was applied to each explanatory variable to evaluate the effect size of each variable on the overall effect measurement, generating four models in addition to the null model (without variables).

After defining the meta-analysis models, we calculated the probability of yield increase, which evaluates the probability of a given treatment to increase the yield to a given level. This was performed using Equation 3 (PAUL et al., 2010; MADDEN; PAUL, 2011):

$$
p_{\vartheta}=\operatorname{Pr}\left(\zeta_{\text {new }}<\vartheta\right)=\Phi((\vartheta-\hat{\zeta}) / \hat{\sigma}) \text {, }
$$

where $\zeta_{\text {new }}$ is the treatment effect, $\Phi$ is the cumulative distribution function of the standard normal distribution, and $\hat{\sigma}$ is the estimated standard deviation among the studies. In the above example, $\zeta_{\text {new }}$ is less than $\vartheta=0$ (equivalent to the probability that the treatment has no effect).

\section{Results and Discussion}

The meta-analysis null model for the effect of biostimulant application on off-season corn yield estimated an average yield increase of $342.1 \mathrm{~kg}$ $\mathrm{ha}^{-1}$, with 95\% confidence interval (Figure 2) ranging from 301.2 to $383.0 \mathrm{~kg} \mathrm{ha}^{-1}$ and statistical significance at $\mathrm{p} \leq 0.01$. Heterogeneity was high (Q: $\mathrm{p}<0.0001 ; \mathrm{I}^{2}:>75 \%$ ), indicating variances between the trials. These variances may originate from variables not analyzed in the present study, but may be partly explained by the moderator variables considered in the present study: number of applications (1, 2, or 3), time of application (V8, $\mathrm{VT}, \mathrm{R} 1, \mathrm{~V} 8+\mathrm{VT}, \mathrm{V} 8+\mathrm{R} 1, \mathrm{VT}+\mathrm{R} 1$, or $\mathrm{V} 8+\mathrm{VT}+\mathrm{R} 1$ ), water stress (with and without), and region where the trial was performed (South and Cerrado regions) (Table 1).

Figure 2. Meta-analysis of the null model (overall) estimated effect measurement, and respective number of cases analyzed (k), for the 287 effect measurements obtained for 41 trials analyzed, with 95\% confidence interval.

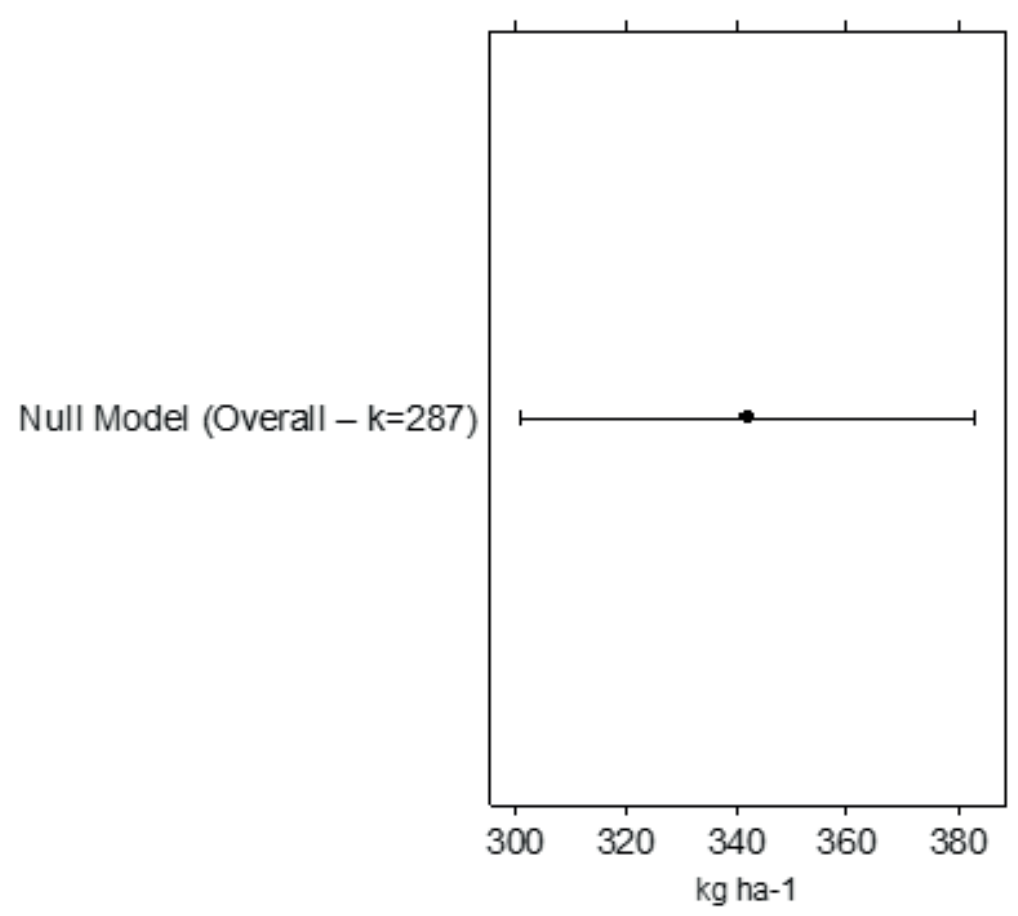


Table 1. Statistics for the meta-analysis using a random effect (overall) and mixed-effects model (moderator variables).

\begin{tabular}{|c|c|c|c|c|c|c|c|c|}
\hline Model & & ${ }^{\mathrm{b}} \mathrm{K}$ & ${ }^{\mathrm{c}} \mathrm{I}^{2}$ & ${ }^{\mathrm{d}} \mathrm{ME}^{3}$ & $\mathrm{e} p$ & $\begin{array}{l}{ }^{\mathrm{f}} \text { Low } \\
\text { lim. }\end{array}$ & $\begin{array}{l}{ }^{\mathrm{f}} \mathrm{Up} \\
\text { lim. }\end{array}$ & ${ }^{\mathrm{g}} \mathrm{Tau}$ \\
\hline Overall (null) & & 287 & 99.75 & 342.1 & $<0.0001$ & 301.2 & 383.0 & 352.9 \\
\hline${ }^{\mathrm{a}}$ Moderator variables & Group & & & & & & & \\
\hline \multirow{4}{*}{$\begin{array}{l}{ }^{1} \text { Number of } \\
\text { Applications }\end{array}$} & 1 & 123 & & 244.7 & $<0.0001$ & 180.8 & 308.6 & \multirow{4}{*}{360.9} \\
\hline & & & $99.76 \%$ & & & & & \\
\hline & 2 & 123 & & 387.1 & $<0.0001$ & 323.2 & 451.1 & \\
\hline & 3 & 41 & & 499.1 & $<0.0001$ & 388.4 & 609.8 & \\
\hline \multirow{7}{*}{${ }^{2}$ Time of application } & V8 & 41 & \multirow{7}{*}{$99.76 \%$} & 189.9 & $<0.0001$ & 79.8 & 299.9 & \multirow{7}{*}{358.8} \\
\hline & VT & 41 & & 228.2 & $<0.0001$ & 118.2 & 338.3 & \\
\hline & $\mathrm{R} 1$ & 41 & & 316.0 & $<0.0001$ & 206.0 & 426.1 & \\
\hline & $\mathrm{V} 8+\mathrm{VT}$ & 41 & & 424.7 & $<0.0001$ & 314.6 & 534.7 & \\
\hline & $\mathrm{V} 8+\mathrm{R} 1$ & 41 & & 380.5 & $<0.0001$ & 270.5 & 490.6 & \\
\hline & $\mathrm{VT}+\mathrm{R} 1$ & 41 & & 356.2 & $<0.0001$ & 246.1 & 466.3 & \\
\hline & $\mathrm{V} 8+\mathrm{VT}+\mathrm{R} 1$ & 41 & & 499.1 & $<0.0001$ & 389.1 & 609.1 & \\
\hline \multirow[t]{2}{*}{$\begin{array}{c}{ }^{3} \text { Occurrence of water } \\
\text { stress }\end{array}$} & with & 273 & $99.74 \%$ & 346.0 & $<0.0001$ & 305.6 & 386.4 & \multirow[t]{2}{*}{372.1} \\
\hline & without & 14 & & 266.3 & 0.0775 & 29.4 & 562.0 & \\
\hline \multirow[t]{2}{*}{${ }^{4}$ Region } & South & 161 & $99.96 \%$ & 372.1 & $<0.0001$ & 314.7 & 429.5 & \multirow[t]{2}{*}{370.9} \\
\hline & Cerrado & 126 & & 303.7 & $<0.0001$ & 238.8 & 368.6 & \\
\hline
\end{tabular}

${ }^{a}$ Moderator variables: ${ }^{1}$ Number of applications: (1, 2, and 3); ${ }^{2}$ Time of application (V8, VT, R1, V8+VT, V8+R1, VT+R1, and $\mathrm{V} 8+\mathrm{VT}+\mathrm{R} 1) ;{ }^{3}$ Water stress (with and without), ${ }^{4}$ Region where the trial was performed (South and Cerrado region); ${ }^{\mathrm{b}} \mathrm{Number}$ of cases analyzed $(\mathrm{K})$; ${ }^{\mathrm{c}}$ Heterogeneity of the studied variables $\left(I^{2}\right)$; ${ }^{\mathrm{d}}$ Meta-analysis statistics, point estimate $\left(\mathrm{kg} \mathrm{ha}^{-1}\right)$; ${ }^{\mathrm{e}} \mathrm{p}$-value (significance level); ${ }^{\mathrm{f}}$ confidence interval $\left(\mathrm{kg} \mathrm{ha}{ }^{-1}\right.$; upper and lower limits);. ${ }^{\mathrm{g}}$ Variance between trials $\left(\mathrm{Tau}^{2}\right)$.

All moderator variables were significantly different from zero $(\mathrm{p}<0.01)$, with $95 \%$ confidence interval, with the exception of the group "without stress" within the moderator variable "presence of water stress" $(p=0.077)$ (Table 1$)$. The meta-analysis results presented in Figure 3 show that the result for the group "without stress" was not significant, because the confidence interval crosses the zero line. The meta-analytic estimates for group "without stress" were lower than those for group "with stress." However, group "without stress" presented a higher confidence interval, ranging from -29.4 to 562.0 and encompassing the confidence interval for group "with stress" (305.6 to 386.4). This indicates that the estimation precision was lower for group "without stress" due to larger 95\% confidence interval, which can be explained by the small number of trials included in this group $(\mathrm{k}=14)$.

Corn is a C4 plant, highly dependent on leaf architecture and expansion. It is able to maximize the incidence of photosynthetically active radiation. When balanced, these factors enable high final grain yield in the absence of water stress (BERGAMASCHI et al., 2006). Biostimulants may change plant hormonal status and greatly affect plant growth and health (ZANG; SCHMIDT, 2000). These products increase plant antioxidant activity, especially under water stress, extreme temperatures, and herbicide action, amongst other factors. Treatment of plants under stress conditions with biostimulants increases plant antioxidant levels, resulting in more efficient defense systems and better plant development (KARNOK, 2000). Richardson et al. (2004) performed a greenhouse experiment to study how a commercial biostimulant would improve the health and resistance to water stress of 3-year-old trees (Betula papyrifera) and observed that plants treated with the biostimulant presented higher leaf nitrogen concentrations and lower water stress damages. 
Figure 3. Meta-analysis of effect measurements $\left(\mathrm{kg} \mathrm{ha}^{-1}\right)$ estimated using the mixed-effects model and the moderator variables: number of applications $(1,2$, or 3), time of application (V8, VT, R1, V8+VT, V8+R1, VT+R1, and $\mathrm{V} 8+\mathrm{VT}+\mathrm{R} 1$ ), water stress (with or without), and region were the trials were performed (South and Cerrado region). k: number of cases in each model or group from a total of 287 effect measurements obtained from 41 trials, with $95 \%$ confidence interval.

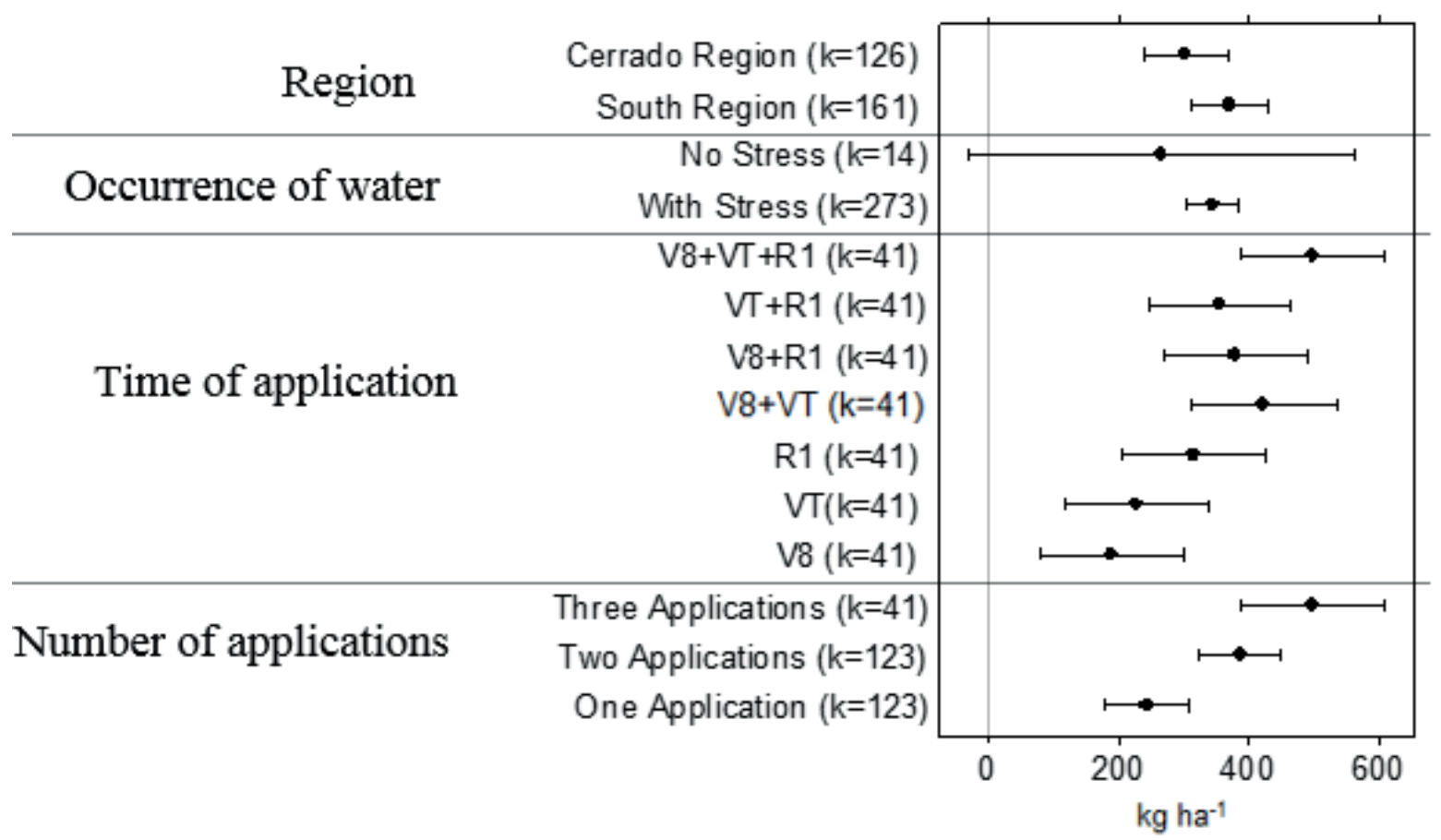

Corn cultivation regions in tropical zone of Brazil can be separated into South, below the 24th parallel, and Cerrado. The meta-analytic estimates were higher for South than for Cerrado region. The average yield of the off-season corn is $5689 \mathrm{~kg} \mathrm{ha}^{-1}$ in Cerrado and $5632 \mathrm{~kg} \mathrm{ha}^{-1}$ in the South (CONAB, 2015). The meta-analytic estimates were $372.1 \mathrm{~kg}$ $\mathrm{ha}^{-1}$ for the South and $303.7 \mathrm{~kg} \mathrm{ha}^{-1}$ for Cerrado, both being significant $(\mathrm{p}<0.01)$. This difference between the regions can be explained by the higher number of studies analyzed for the South $(\mathrm{k}=161)$ as compared to that for the Cerrado region $(\mathrm{k}=126)$.

Regarding the moderator variable "time of application," when single applications were analyzed, the meta-analysis estimates were higher for applications in R1. However, when double applications were analyzed, the best meta-analytic estimates were obtained for no applications in R1, i.e., V8+VT. Silva (2009) and Ramos (2011) studied fungicide application in corn crops and observed higher yield for applications during V8 and VT, indicating that corn is physiologically more sensitive to product application during these stages.

The moderator variable "number of applications" presented the largest variations between the groups, with yield response increasing with increasing number of applications: $180.8 \mathrm{~kg} \mathrm{ha}^{-1}$ for one application, $323.2 \mathrm{~kg} \mathrm{ha}^{-1}$ for two applications, and $388.4 \mathrm{~kg} \mathrm{ha}^{-1}$ for three applications.

Figure 3 shows the results of the meta-analysis of the data for the analyzed variable (Global) and the respective moderator variable groups and the number of cases in each group $(\mathrm{k})$. The meta-analysis result showed that foliar biostimulant (GAAP) application had positive effects on corn yield $(\mathrm{p}<$ 0.0001 ). The highest average point estimates was observed for three applications, during vegetative 
and reproductive stages $(\mathrm{V} 8+\mathrm{VT}+\mathrm{R} 1)$, in trials performed in the South, and under water stress conditions, and they were positively prominent among the remaining groups analyzed.

Using the meta-analysis results, the meta-analytic estimates and the variability between studies, the probability of the biostimulant application resulting in yield increase higher than zero or at levels of 2, 5, and 10 bags each $60 \mathrm{~kg} \mathrm{ha}^{-1}$ was calculated (Table 2) and estimated at 83.7\%, 73.5\%, 54.7\%, and $23.2 \%$, respectively, for the overall analysis; for the variable "number of applications" it was estimated at $75.1 \%, 63.5 \%, 43.9 \%$, and $16.2 \%$ for one application, $85.9 \%, 77.0 \%, 59.5 \%$, and $27.7 \%$ for two applications, and 91.7\%, 85.3\%, 70.9\%, and $38.9 \%$ for three applications, respectively; for "time of application" it was estimated at $70.1 \%$, $57.7 \%, 37.9 \%$, and $12.6 \%$ for $\mathrm{V} 8,73.7 \%, 61.8 \%$, $42.0 \%$, and $15.0 \%$ for VT, $81.1 \%, 70.7 \%, 51.7 \%$, and $1.4 \%$ for R1, $88.1 \%, 80.2 \%, 63.5 \%$, and $31.2 \%$ for $\mathrm{V} 8+\mathrm{VT}, 85.5 \%, 76.6 \%, 58.8 \%$, and $27.0 \%$ for $\mathrm{V} 8+\mathrm{R} 1,83.9 \%, 74.4 \%, 56.2 \%$, and $24.8 \%$ for $\mathrm{VT}+\mathrm{R} 1$, and $91.7 \%, 85.4 \%, 71.0 \%$, and $38.9 \%$ for $\mathrm{V} 8+\mathrm{VT}+\mathrm{R} 1$, respectively; for "presence of water stress" it was estimated at $79.1 \%, 69.3 \%, 50.1 \%$, and $21.1 \%$ "with stress" and $76.2 \%, 65.2 \%, 46.3 \%$, and $18.4 \%$ "without stress," respectively; and for the variable "region where the trial was performed" it was estimated at $84.2 \%, 75.1 \%, 57.7 \%$, and $26.9 \%$ for the South region and $79.3 \%, 68.9 \%, 50.3 \%$, and $21.2 \%$, for the Cerrado region, respectively.

Table 2. Probability of the positive yield increase, negative yield increase, and increase of 2, 5, and 10 (bags $60 \mathrm{~kg}$ $\mathrm{ha}^{-1}$ ) resulting from foliar application of the biostimulant GAAP to corn crops. Data obtained from 41 trials. Overall analysis of 287 effect measurements, and analysis of the moderator variable groups: one application, two applications, three applications, application in V8, VT, R1, V8+VT, V8+R1, VT+R1, or V8+VT+R1, with or without water stress, and trials conducted in the South or Cerrado region.

\begin{tabular}{lcccc}
\hline \multicolumn{1}{c}{ TREATMENTS } & $\begin{array}{c}\text { POSITIVE } \\
(\mathbf{\%})>\mathbf{0}\end{array}$ & $\begin{array}{c}\text { 2 BAGS (\%) } \\
\mathbf{> 2}\end{array}$ & $\begin{array}{c}\mathbf{5} \text { BAGS (\%) } \\
\mathbf{> 5}\end{array}$ & $\begin{array}{c}\mathbf{1 0} \text { BAGS (\%) } \\
\mathbf{2 1 0}\end{array}$ \\
\hline Overall & 83.7 & 73.5 & 54.7 & 23.2 \\
\hline One application & 75.1 & 63.5 & 43.9 & 16.2 \\
Two applications & 85.9 & 77.0 & 59.5 & 27.7 \\
Three applications & 91.7 & 85.3 & 70.9 & 38.9 \\
Applied in V8 & 70.1 & 57.7 & 37.9 & 12.6 \\
Applied in VT & 73.7 & 61.8 & 42.0 & 15.0 \\
Applied in R1 & 81.1 & 70.7 & 51.7 & 21.4 \\
Applied in V8+VT & 88.1 & 80.2 & 63.5 & 31.2 \\
Applied in V8+R1 & 85.5 & 76.6 & 58.8 & 27.0 \\
Applied in VT+R1 & 83.9 & 74.4 & 56.2 & 24.8 \\
Applied in V8+VT+R1 & 91.7 & 85.4 & 71.0 & 38.9 \\
With stress & 79.1 & 69.3 & 50.1 & 21.1 \\
Without stress & 76.2 & 65.2 & 46.3 & 18.4 \\
South & 84.2 & 75.1 & 57.7 & 26.9 \\
Cerrado & 79.3 & 68.9 & 50.3 & 21.2 \\
\hline
\end{tabular}

\section{Conclusion}

The meta-analysis revealed that application of the biostimulant GAAP had a positive effect on the off-season corn, as indicated by a significant metaanalytic response $(\mathrm{p}<0.0001)$ and a positive yield increase of $83.7 \%$. 
Regarding the tested moderator variables, three applications of GAAP, during the phenological stages $\mathrm{V} 8+\mathrm{VT}+\mathrm{R} 1$, under water stress conditions, in trials conducted in the South region of Brazil, presented higher meta-analytic estimates and higher probabilities of yield increase.

Biostimulant application increased corn crop yield with an overall meta-analytic estimate between $301.2 \mathrm{~kg} \mathrm{ha}^{-1}$ and $383 \mathrm{~kg} \mathrm{ha}^{-1}$.

\section{References}

ARENDS, L. R.; HOES, A. W.; LUBESN, J.; GROBBEE, D. E.; STIJNEN, T. Baseline risk as predictor of treatment benefit: three clinical meta-re-analyses. Statistics in Medicine, London, v. 19, n. 24, p. 3497-3518, 2000.

ARENDS, L. R.; VOKÓ, Z.; STIJNEN, T. Combining multiple outcome measures in a meta-analysis: an application. Statististics in Medicine, London, v. 22, n. 8, p. 1335-1353, 2003.

ÁVILA, M. R.; BRACCINI, A. L.; SCAPIM, C. A.; ALBRECHT, L. P.; TONIN, T. A.; STÜLP, M. Bioregulator application, agronomic efficiency, and quality of soybean seeds. Scientia Agricola, Piracicaba, v. 65, n. 6, p. 604-612, 2008.

BELANSON, E. Avaliação de diferentes produtos enraizadores no rendimento de grão do trigo. Assis Chateaubriand, Paraná: FAG, 2008. Available at: <http:// www.fag.edu.br/tcc/2007/Agronomia/avalicacao_dos diferentes_produtos_no_rendimento_de_graos_dotrigo.pdf $>$ Accessed at: 13 sept. 2010.

BERGAMASCHI, H.; DALMAGO, G. A.; COMIRAN, F.; BERGONCI, J. I.; MÜLLER, A. G.; FRANÇA, S.; SANTOS, A. O.; RADIN, B.; BIANCHI, C. A. M.; PEREIRA, P. G. Déficit hídrico e produtividade na cultura do milho. Pesquisa Agropecuária Brasileira, Brasília, v. 41, n. 2, p. 243-249, 2006.

BOISSEL, J. P. Méta-analyse des essais cliniques; intérêts et limites. Archives des Maladies du Coeur et des Vaisseaux, Paris, v. 87, n. 4, p. 11-17, 1994.

BOISSEL, J. P.; BLANCHARD, J.; PANAK, E.; PEYRIEUX, J. C.; SACKS, H. Considerations for the meta-analysis of randomized clinical trials. Summary of a panel discussion. Controlled Clinical Trials, New York, v. 10 , n. 3, p. 254-281, 1989.

BORENSTEIN, M.; HedGeS, L. V.; HIGGINS, J. P. T.; ROTHSTEIN, H. R. Introduction to meta-analysis.
Wiley and Sons: United Kingdom, 2009. 450 p.

CALVO, N. S.; FANTIN, L. H.; CANTERI, M. G.; SUMIDA, C. H. Meta-analytic model in the evaluation of yield increase with the use of fungicides to control Sclerotinia sclerotiorum. Agronomy Science and Biotechnology, Londrina, v. 2, n. 2, 2016.

CASTRO, P. R. C.; VIEIRA, E. L. Aplicações de reguladores vegetais na agricultura tropical. Guaíba: Livraria e Ed. Agropecuária, 2001.

COMPANHIA NACIONAL DE ABASTECIMENTO - CONAB. Acompanhamento da safra brasileira de grãos, v.1 - Safra 2015/2016, n.1-primeiro levantamento, Brasília: CONAB, 2015, p. 66-72. Available at: <http://www.conab.gov.br/OlalaCMS/ uploads/arquivos/1510_09_09_03_07_boletim_graos outubro_2015.pdf $>$. Accessed at: 26 oct. 2015.

CSINZINSZKY, A. A. Response of two bell peppers (Capsicum annum L.) cultivars to foliar and soil-applied biostimulants. Proceedings Soil and Crop Science Society of Florida, Bradenton, v. 49, n.14, p. 199-203, 1990.

D'AGostino, R. B.; WEINTRAUB, M. Metaanalysis: a method for synthesizing research. Clinical Pharmacology \& Terapeutics, Philadelphia, v. 58, n. 6, p. 605-616, 1995.

DALLA LANA, F.; ZIEGELMANN, P. K.; MAIA, H. N. A. de; GODOY, C. V.; DEL PONTE, E. M. Meta-analysis of the relationship between crop yield and soybean rust severity. Phytopathology, St. Paul, v. 105, n. 3, p. $307-$ $315,2015$.

DELLA LIBERA, A. M. Efeito de bioestimulantes em caracteres fisiológicos e de importância agronômica em milho (Zea mays L.). 2010. Trabalho de Conclusão de Curso (Graduação em Agronomia) - Departamento de Estudos Agrários, Universidade Regional do Noroeste do Rio Grande do Sul, Ijuí.

EMPRESA BRASILEIRA DE PESQUISA AGROPECUÁRIA - EMBRAPA. Cultivo do milho. Sete Lagoas: EMBRAPA-CNPMS, 2008. Disponível em: <http://www.cnpms.embrapa.br/publicacoes/milho / economia.htm $>$. Acesso em: 20 maio 2014.

FANTIN, L. H.; CANTERI, M. G.; SILVA A. L. da; TUPICH, F. L. B.; MADDEN, L. V. Contribution of soybean seed treatment with Fluquinconazole to manage yield losses caused by Phakospora pachyrhizi using meta-analysis. African Journal of Agricultural Research, Johannesburg, v. 11, n. 39, p. 3880-3888, 2016.

FIELD, A. P.; GILLETT, R. How to do a meta-analysis. British Jornal of mathematical and Statistical Psycology, London, v. 63, n. 3, p. 665-694, 2010. 
HIGGINS, J. P.; THOMPSON, S. G. Quantifying heterogeneity in a meta-analysis. Statistics in Medicine, London, v. 21, n. 11, p. 1539-1558, 2002.

HIGGINS, J. P.; THOMPSON, S. G.; DEEKS, J. J.; ALTMAN, D. G. Measuring inconsistency in metaanalyses. British Medical Journal, London, v. 327, n. 7414, p. 557-560, 2003.

HSU, H. H. The absorption and distribution of metalosastes from foliar fertilization. In: ASHMEAD, H. D.; ASHMEAD, H. H.; MILLER, G. W.; HSU, H. H. (Ed.). Foliar feeding of plants with amino acid chelates. Park Ridge: Noyes Publications, 1986. p. 45-61.

JANEGITZ, M. C.; SERRANO, F. B.; OLIVEIRA, P. M. A.; PAULA, J. C. B.; HERMAM, E. R. Efeitos de bioestimulantes via semente no desenvolvimento inicial das raízes de milho e sorgo. Paraquaçu PaulistaSP, 2008. Disponível em: <//www.diadecampo.com. br/arquivos/materiais/\%7b35996e9c-f8bo-4dacbaadbe 317950c245\% 7d_77_2.pdf>. Acesso em: 13 set. 2010.

KARNOK, K. J. Promises, promises: can biostimulants deliver? Golf Course Management, Athens, v. 68, n. 8, p. 67-71, 2000.

MADDEN, L. V.; PAUL, P. A. Meta-analysis for evidence synthesis in plant pathology: an overview. Phytopathology, St. Paul, v. 101, n. 1, p. 16-30, 2011.

MALAVOLTA, E. Elementos de nutrição mineral de plantas. Piracicaba: POTAFÓS, 1980. 251 p.

NGUGI, H. H.; ESKER, P. D.; SCHERM, H. Metaanalysis to determine the effects of plant disease management measures: review and case studies on soybean and apple. Phytopathology, St. Paul, v. 101, n. 1, p. 31-41, 2011.

ONO, E. O.; RODRIGUES, J. D.; SANTOS, S. O. Efeito de fitorreguladores sobre o desenvolvimento de feijoeiro (Phaseolus vulgaris L.) cv Carioca. Revista Biociências, Taubaté, v. 5, n. 1, p. 7-13, 1999.

PAUL, P. A.; LIPPS, P. E.; HERSHMAN, D. E.; MCMULLEN, M. P.; DRAPER, M. A.; MADDEN, L. V. Efficacy of triazole-based fungicides for fusarium head blight and deoxynivalenol control in wheat: a multivariate meta-analysis. Phytopathology, St. Paul, v. 98, n. 9, p. 999-1011, 2010.

R DEVELOPMENT CORE TEAM. R: a language and environment for statistical computing. R Foundation for Statistical Computing, Vienna, Austria, 2015. Available at: <http://www.R-project.org >. Accessed at: 28 Sept. 2016.
RAMOS, J. P. Frequência e época de aplicação de fungicidas e seus efeitos em híbridos de milho (Zea mays L.). Tese de Mestrado (Dissertação) - Universidade Federal de Santa Maria, Santa Maria.

RICHARDSON, A. D.; AIKENS, M.; BERLYN, G. P.; MARSHALL, P. Drought stress and paper birch (Betula papyrifera) seedlings: effects of an organic biostimulant on plant health and stress tolerance, and detection of stress effects with instrumental-based, noninvasive methods. Journal of Arboriculture, Champaign, v. 30, n. 1, p. 52-61, 2004.

RODRIGUES, C. L.; ZIEGELMAN, P. K. Metanálise: um guia prático. Revista HCPA, Porto Alegre, v. 30, n. 4, p. 436-447, 2010.

ROSENBERG, M. S.; GARRET, K. A.; SU, Z.; BOWDEN, R. L. Meta-analysis in plant pathology: synthesizing research results. Phytopathology, St. Paul, v. 94, n. 9, p. 1013-1017, 2004.

SILVA, L. H. C. da; CAMPOS, H. D.; SILVA, J. R. C.; MORAIS, E. B. de; CARMO, G. L. do. Controle químico de doenças foliares no milho safrinha. In: SEMINÁRIO NACIONAL DE MILHO SAFRINHA, 10., 2009. Rio Verde. Anais... Rio Verde: FESURV, 2009. p. 131-140.

TAIZ, L.; ZIEGER, E. Auxina: o hormônio de crescimento. In:___. (Ed.). Fisiologia vegetal. 3. ed. Porto Alegre: Artmed, 2004. p. 449-484.

TWEDDELL, R. J.; PELERIN, S.; CHABOT, R. A. A two-year field study of a commercial biostimulant applied on maize as seed coating. Canadian Journal of Plant Science, Quebec, v. 80, n. 4, p. 805-807, 2000.

VASCONCELOS, A. C. F. de. Uso de bioestimulantes nas culturas de milho e de soja. 2006. Tese (Doutorado em Agronomia) - Escola Superior de Agricultura Luiz de Queroz, Piracicaba.

VIEIRA, E. L. Ação de bioestimulantes na germinação de sementes, vigor de plântulas, crescimento radicular e produtividade de soja (Glycine max (L) Merril), feijoeiro (Phaseolus vulgaris L.) e arroz (Oryza sativa L.). 2001. Tese (Doutorado em Agronomia) - Escola Superior de Agricultura Luiz de Queiroz. Universidade de São Paulo, Piracicaba.

ZANG, X.; SCHMIDT, R. E. Hormone-containing products' impact on antioxidant status of tall fescue and creeping bentgrass subjected to drought. Crop Science, Madison, v. 40, n. 5, p. 1344-1249, 2000. 
